\title{
The digital transformation triangle. A framework to set the foundations for a successful digital journey
}

\author{
Jon Bazán Martínez \\ bazan.matinez.jon@gmail.com / University of Manchester \\ Manchester, United Kingdom \\ Lissette Tucto Mechán \\ lissette.tucto@gmail.com / University of Manchester \\ Manchester, United Kingdom
}

Receipt: 1-7-2018 / Acceptance: 20-8-2018

\begin{abstract}
The objective of the research is to analyze the most common barriers to a successful digital transformation. The research is based on case studies and industry papers to find the top barriers to a successful digital transformation. The findings show that cultural issues, the presence of archaic IT systems and applications, the lack of digital skills, and the lack of clear leadership vision are the top barriers. To conclude, a roadmap for digitalization of business is provided as a response to those businesses looking for setting the foundations for a successful digital transformation. This roadmap starts with the business needs and goes to escalation once the benefit is proven.
\end{abstract}

KEYWORDS: digital transformation, digital growth, the digital transformation triangle, business transformation, digital roadmap

\section{El triángulo de la transformación digital. Un marco para establecer las bases de un viaje digital exitoso}

REsumen. El objetivo de la investigación es analizar las barreras más comunes para alcanzar una exitosa transformación digital. La investigación se basa en estudio de casos y artículos de la industria para encontrar las más importantes barreras para una exitosa transformación digital. Los resultados muestran que los temas culturales, la presencia sistemas y aplicaciones de TI arcaicas, la falta de habilidades digitales, y la falta de una visión clara de liderazgo son las principales barreras. En conclusión, se entrega una hoja de ruta para la digitalización del negocio como respuesta a aquellos negocios que buscan establecer los cimientos para una exitosa transformación digital. Esta hoja de ruta comienza con las necesidades del negocio y va escalando una vez que el beneficio es alcanzado.

Palabras ClaVe: transformación digital, crecimiento digital, el triángulo de la transformación digital, transformación del negocio, hoja de ruta digital 


\section{INTRODUCTION}

The worldwide expenditure on digital transformation (hardware, software, and services) is expected to be $\$ 1.3$ trillion in 2018, with a compound annual growth rate (CAGR) of $17.9 \%$ over the 2016-2021 period (IDC, 2018). This growth is aligned with the insights found by the IDG survey (IDG, 2018), where $89 \%$ of the surveyed organizations have adopted or have plans to adopt a digital-first strategy.

Even if media, telecom, financial services, and retail are the dominant adopters in terms of digitalization, all industries are being disrupted by the digitalization trend, combining information technologies to grow.

As per The World Economic Forum (2016), the transformative power of information technologies lies in their combinatorial effects, which accelerate progress exponentially and are reaching critical mass today.

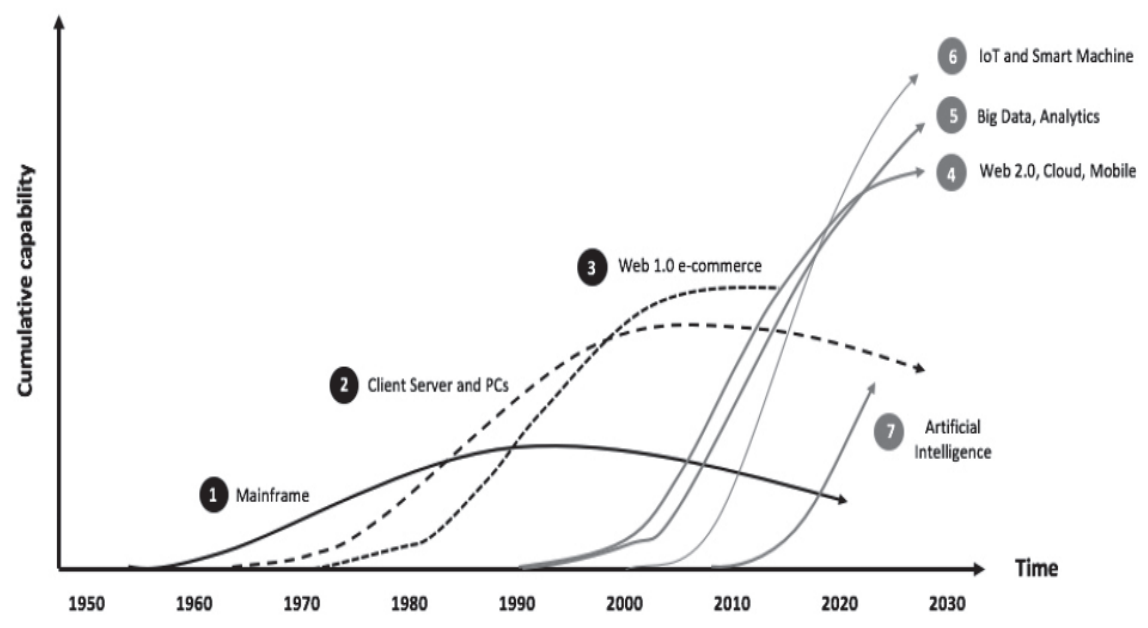

Figure 1. Combinatorial effects of new technologies

Source: World Economic Forum (2016)

Hence, digital transformation refers to the integration and combination of information technologies to business in order to change the way to deliver value to the customer and the way the business operates. As a result, businesses look for digitalization in order to improve customer experience and operational efficiency expecting both top-line and bottom-line growth.

Nevertheless, a survey conducted by Bain \& Company with 1,000 organizations across the world showed that only $5 \%$ of the companies involved in digital transformation projects reported that they had achieved their expectations. 
This paper aims at understanding the most common barriers that companies encounter when they undertake their digitalization journey.

\section{Methodology}

This paper is based on a research process that follows the stages mentioned below:

1) Research of industry players: case studies and reports to understand the current state of digital transformation across businesses.

2) Analysis of drivers behind successful digital transformation strategies.

3) Conclusions and proposal of a digital roadmap.

These reports and journals have been obtained from online sources and educational databases. This information provides a view of the landscape of these new trends, and also strengthens the recommendations proposed.

\section{Results}

Digitalization is causing changes across multiple aspects of business, generating opportunities for value creation, while diverse sources of risk also appear. According to the 2018 Global CEO Outlook survey conducted by KPMG International, only $71 \%$ of CEOs are prepared to lead their organizations through a radical transformation (KPMG, 2018).

As per The Digital Culture Challenge (Capgemini, 2017), where a survey was conducted with more than 1,700 people across the world, including senior executives, managers, and employees, more than 6 out of 10 respondents consider culture as the number one barrier to success in digital transformation.

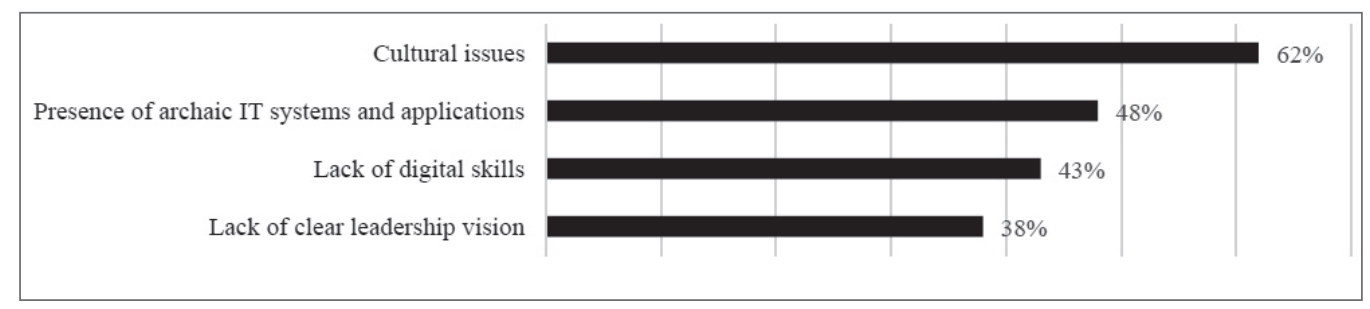

Figure 2. Hurdles to digital transformation

Source: Capgemini Consulting (2017) 
As per The Boston Consulting Group, when assessing 40 recent digital transformations, nearly $80 \%$ of the companies that explicitly addressed culture change reported strong performance, while none of those companies that neglected culture change reported strong performance (Hemerling, Kilmann, Danoesastro, Stutts, \& Ahern, 2018).

Businesses are being disrupted by technology in a way that companies can optimize their relationship with their customers and suppliers, as well as their internal processes, resulting in revenue growth and cost reduction. The research process shows three key elements needed for every digital transformation journey: business strategy alignment, IT capabilities, and culture.

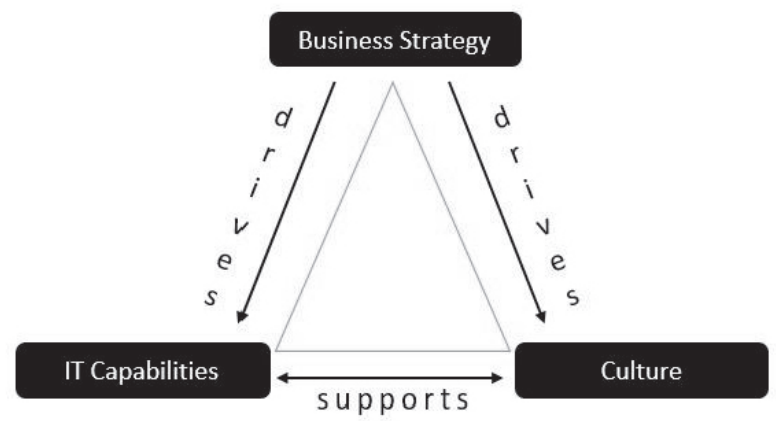

Figure 3. The digital transformation triangle

Elaborated by the authors

Companies are failing in their digitalization process as they are building their IT capabilities and digital transformation teams without a previous business strategy. Companies need to scope their business needs for the short, medium and long term within their strategy first, and then build the technology, infrastructure, and culture that will support that strategy.

The IT capabilities are those virtual elements or platforms and infrastructures that help businesses digitalize their core. The following lines summarize such technologies being used nowadays to solve front-end and back-end issues by companies:

Big data: Its purpose is to extract and analyze the data generated by the business to create value from it. As an example, Big Data is able to personalize the value proposition for the customer (front-end) as well as doing predictive maintenance for the company (back-end) to improve profitability.

Cloud computing: This technology allows businesses to rely on computational and storage capabilities offered by third parties in order to reduce the IT expenditure (both software and hardware). The key of this technology is scalability. Companies can scale easily as the 
business grows, since they no longer need to build their own IT infrastructure, resulting in a reduction of capital expenditure.

Artificial intelligence: AI algorithms are capable of substituting human action in many aspects of business. This technology relies on training a machine to learn, so that it reasons and solves problems without the need for a human. Currently, AI is capable of understanding human speech, recognizing images, and performing logical processes.

Internet of things (IoT): The term IoT includes any device connected to the Internet which is increasingly being used for devices (from sensors to wearables) that communicate with each other. The combination of such devices makes possible to gather information and analyze it to help people with particular tasks.

As well as IT capabilities, the culture in the organization has to be aligned and driven by the business strategy to support the digital transformation process. Apart from the exploitation of the business processes, exploration is needed for a successful digital transformation. Exploration is the process where people in the organization think of all the value chain and stakeholders of the business, define projects and technologies to optimize its performance, and explore new options for growth.

The team in charge of exploration can be organized in several ways. There could be a digital team per each business function, a central team interacting with all functions, or even an external team acting as a digital incubator for the company. However, it is necessary that the digital transformation of the company is driven by a specific group of people who are aligned with the managerial board and have access to every function across the business.

\section{CONCLUSION AND RECOMMENDATIONS}

After analyzing the particular business needs of the company at the strategic level, it is concluded that digitalization (building of IT capabilities and culture change) will support the strategy for both top-line and bottom-line growth. The following table suggests a roadmap for such digitalization. 
Table 1

General roadmap for digital transformation

\begin{tabular}{|l|l|l|l|}
\hline \multicolumn{1}{|c|}{ Stage } & \multicolumn{1}{|c|}{ Primary Research } & \multicolumn{1}{|c|}{ Secondary Research } & \multicolumn{1}{c|}{ Result } \\
\hline $\begin{array}{l}\text { Exploration and } \\
\text { definition of } \\
\text { business needs }\end{array}$ & $\begin{array}{l}\text { Interviews with internal } \\
\text { stakeholders and initial } \\
\text { brainstorming }\end{array}$ & $\begin{array}{l}\text { Desk research on digital } \\
\text { initiatives of incumbents, } \\
\text { and disruptive competitors } \\
\text { and suppliers }\end{array}$ & $\begin{array}{l}\text { Definition of digital } \\
\text { transformation needs (to-be) } \\
\text { and current digital maturity } \\
\text { (as-is) }\end{array}$ \\
\hline $\begin{array}{l}\text { Definition } \\
\text { of potential } \\
\text { technologies to } \\
\text { address } \\
\text { the needs }\end{array}$ & $\begin{array}{l}\text { Feasibility of the specific } \\
\text { technologies through } \\
\text { interviewing experts, } \\
\text { vendors, and customers }\end{array}$ & $\begin{array}{l}\text { Desk research on specific } \\
\text { technologies and past } \\
\text { implementations }\end{array}$ & $\begin{array}{l}\text { Portfolio of potential } \\
\text { technologies to be } \\
\text { deployed as part of the } \\
\text { digital transformation of the } \\
\text { organization }\end{array}$ \\
\hline Proof of concept & $\begin{array}{l}\text { Internal validation with } \\
\text { stakeholders }\end{array}$ & $\begin{array}{l}\text { Further research on IT } \\
\text { capabilities and culture } \\
\text { change needed to propose } \\
\text { technologies to be deployed }\end{array}$ & $\begin{array}{l}\text { Detailed business case and } \\
\text { planning for implementation } \\
\text { of technologies }\end{array}$ \\
\hline Scalability & $\begin{array}{l}\text { Interviews with potential } \\
\text { partners and funding } \\
\text { bodies }\end{array}$ & $\begin{array}{l}\text { Desk research on future } \\
\text { needs in order to escalate }\end{array}$ & Strategy for future growth \\
\hline
\end{tabular}

Elaborated by the authors

It is important to highlight the importance of the first-stage exploration and definition of needs, as it sets the long-term vision of the company and defines its current digital maturity, addressing the following dimensions: human resources, technology resources, data strategy, content strategy, channel strategy, and social business strategy. This assessment will allow to identify, articulate, and execute digital opportunities.

\section{REFERENCES}

Bughin, J., Catlin, T, Hirt, M. \& Willmott, P. (2018). Why digital strategies fail. McKinsey. Retrieved from https://www.mckinsey.com/business-functions/digital-mckinsey/ourinsights/ why-digital-strategies-fail

Capgemini Consulting. (2017). The digital culture challenge: closing the employee-leadership gap. Retrieved from https://www.capgemini.com/consulting/wp-content/uploads/ sites /30/2017/07/dti_digitalculture_report.pdf

Grossman, R. \& Rickards, T. (2015). Digital pulse 2015, thought leadership. Retrieved from http://www.russellreynolds.com/en/Insights/thought-leadership/Documents/ R508039-rr0 057-Digital\%20Pulse\%20v7.pdf

Hemerling, J., Kilmann, J., Danoesastro, M., Stutts, L \& Ahern, C. (2018). It's not a digital transformation without a digital culture. BCG. Retrieved from http://image-src.bcg. 
com/Images/BCG-Its-Not-a-Digital-Transformation-Without-a-Digital-CultureApr-2018-new_tcm9-193272.pdf

IDC. (2017). IDC Forecasts Worldwide Spending on Digital Transformation Technologies to Reach \$1.3 Trillion in 2018. Retrieved from https://www.idc.com/getdoc. jsp?containerId $=$ prUS43381817

IDG. (2018). The State of digital business transformation. Retrieved from https://www.idg. $\mathrm{com} /$ tools-for-marketers/2018-state-of-digital-business-transformation-white-paper/

Ismail, N. (2017). Digital transformation: business first, technology second. Retrieved from https://www.information-age.com/digital-transformation-business-first-technologysecond $-123468564 /$

KPMG. (2017). Global CEO Outlook country reports. Retrieved from https://home.kpmg.com/ xx/en/home/insights/2017/06/2017-global-ceo-outlook-country-reports. Html

Kubrick,K.(2014).Six dimensions ofdigital maturity.Digitalstrategyconference. Retrieved from https://www.onlineauthority.com/blog/six-dimensions-of-digital-maturity-intro ductory-review

Sauvé, D. (2018). New digital maturity model for brand packaging. Retrieved from https:// www.simplifymypackaging.com/home/white-paper-2018-digital-maturity-model-b rand-packaging

The World Economic Forum. (2016). Digital transformation of industries demystifying digital and securing $\$ 100$ trillion for society and industry by 2025. Retrieved from http:// reports.weforum.org/digital-transformation/wp-content/blogs.dir/94/mp/files/ pages /files/ wef1601-digitaltransformation-1401.pdf 
